\title{
Perceived Effects of MBA Degree on Skills Development and Career Advancement: The Case of Pakistan
}

\author{
Ayesha Saba \\ Department of Business Studies, The University of Faisalabad, Faisalabad, Pakistan \\ Babak Mahmood (Corresponding author) \\ Assistant Professor, Department of Sociology, University of Sargodha, Sargodha, Pakistan \\ E-mail: babakmahmood@gmail.com \\ Aroosa Khalid \& Sumaira Aslam \\ Department of Business Studies, The University of Faisalabad, Faisalabad, Pakistan
}

Received: December 17, 2010 Accepted: February 10, 2011 doi:10.5539/ijbm.v6n7p207

\begin{abstract}
This study was conducted to assess the effects of MBA degree on enhancement of skills and career advancement in Pakistan .Business education is getting importance and growing day by day globally and for the sake of assessing worthiness of this degree of business education (MBA) in developing economy of Pakistan 100 professionals( 75 MBA's and 25 others) were studied. Likewise study also focuses on some intervening variables for instance stress management, effective communication, time management, interpersonal skills, self confidence, and analytical skills. Study was conducted in banking industry by selecting people randomly from different managerial ranks. Data were collected through a well designed and structured questionnaire and pre-testing was carried out to examine the efficiency of the instrument. Descriptive and inferential statistical tools were applied and analyses demonstrated that MBA degree has positive effect on career advancement because it sharpens different skills of MBA's and it provides basis for better opportunities and MBA's have diversified skills so they can act as worthy managers.
\end{abstract}

Keywords: Employment, MBA, Skills, Business education, Decision making, Career advancement, Professionals, Time management, Analytical skills

\section{Introduction}

The aim of this study was to access how the business management education at graduate level in Pakistan is helpful in making better managers. A variety of studies are available depicting the career choices for MBAs (Ng, 2008) exploration of MBA's Career success (Hay \& Hodgkinson, 1996) and a need of management education (Kelli, 2004). This study exclusively highlights the perceived effects of MBA degree on employability and career advancement in Pakistan. Education is the essential part of today's changing world. Due to ever shifting requirements of organizations and institutions, it is considered as a key to success and survival in all knowledgeable societies.

It also helps countries to economically grow, reduce poverty and inequalities. According to Mahmood \& Shafique, 2010, "World Bank has stressed that education plays a significant role in building human capabilities and accelerates economic growth through knowledge, skills and creative strength of a society". Also, businesses were dominated by distinction between "gentleman" (owners) and "players" (salaried managers), but even players recruited had rarely received much more than a basic education - the aim was to be trained "on the job" (Caceres, 2008).Furthermore, Governments around the world are more interested to introduce cultures that would promote enterprises, create new ventures and as a result, education systems would be changed, in varying degrees (Kirby, 2004). Pakistan is an underdeveloped country and like many other crises, it is also a victim of poor quality of education which leads it toward economic stagnancy and even downturn rather than growth. Ranis et al. (2000) have empirically shown that over the last decades Pakistan had fallen in categories either of lopsided development, under emphasizing human development, or the downward spiral, where human development is not leading to strong economic growth. Therefore, to bring knowledge-driven growth requires education systems to impart higher-level skills to a rising share of the workforce, foster lifelong learning for citizens and promote international accreditation of a country's educational institutions (Mahmood \& Shafique, 2010) and introduction of professional courses in engineering, law and business is a shift toward it. There is evidence of serious changes in terms of careers offered by organizations (Littler et al., 2003), especially in the case of managers (Cappelli, 1992) and the popular conception surrounding the MBA degree is that it leads to fast 
track career success, typically construed in terms of improved salary and hierarchical position (Hay \& Hodgkinson, 1996). MBA programs were originated in the USA, where the first degrees were awarded at around the turn of the twentieth century and since this time, it is still the most important for the modern manager, has gone through a number of changes (Caceres, 2008). Due to its multipurpose benefits to individuals, organizations and economies it is diffusing very swiftly i.e. Paton, (2001) narrated that the proliferation of business schools and associated management and business development products across the UK has almost reached epidemic proportions. MBA programs provide graduates with the knowledge, competencies, skills and capabilities to perform certain tasks at key positions in the organizations. The literature shows that MBA education is different from country to country based on various demographic factors like culture, geographical locations, differences in behaviors and attitudes of people etc. Some key objectives of the study are as follows:

Assess the value addition of MBA degree of Pakistani institutions in

1) Skills development

2) In employability

3) Career advancement

The following section of this paper presents a review of relevant literature and research questions; in the next section the methodology is narrated; the following section prescribes the main findings and at last conclusions are discussed.

\section{Literature Review}

Master in Business administration (MBA) degree holders are considered as personnel who have ample knowledge about various dimensions of business field. A business school has an organizational culture of its own and plays a central role in shaping the careers of those who take degrees of MBA (Kelan \& Jones, 2009). The Universities, colleges and other institutions are playing an active role in fulfillment of the demands of markets regarding MBAs by adding required skills in their curriculum for degree of MBA.

MBA facilitates the transition from junior role to a much more senior one, the graduates of the top business schools are expected to progress swiftly to the executive suite and successful progression through MBA program thus marks a change of status (Kelan \& Jones, 2009; Hill, 2003, 2007). Usually, a question arises on the value of MBA when a person fails to achieve his career objectives. Pimpa, N. (2008); Hay and Hodgkinson, (2006) explored that a popular purpose of the MBA degree is that it leads to fast track career success, typically construed in terms of improved salary and hierarchical position. Graduates from big institutes are more likely to get career advancement at early stages but there is difficulty to define whether MBA is being done to get higher salaries, to attain position in hierarchy or for learning and development. MBA students are generally thought to have realistic self-concepts and some career directions. Consequently, there may be certain objectives or ambitions which pursuits the person to do MBA i.e. many students are looking to an MBA degree to enhance their employability and to fast track their careers (Hay and Hodgkinson, 2006). Literature identifies several aspects of owner personality that impact the health and profitability of a firm. Some of the characteristics cited in literature are; education, owners experience in business and family history/characteristics (Ahmed, 1997), motivation, skills, knowledge level (Hankinson, 2000) education, personal attributes, managerial and technical competences (Martin and Stains, 1994). Litterateur review above provides the basis for research question stated below and this question would be evaluated further for checking the results of this question in boundaries of Pakistan.

\subsection{Research question}

\section{Is degree of MBA really helpful in skills development and career advancement of managers in Pakistan?}

\section{Material and Methods}

A cross sectional survey was conducted in banking industry of Faisalabad .Respondents from top, middle and lower management according to their relevant qualifications were randomly selected during the study. Due to requirements of study 75 MBA's were selected from different banks for the sake of checking their enhanced capabilities and 1/4 (25) respondents were selected with other qualifications for the purpose of checking differences in skills of non MBA's and their perceptions about MBA's. For checking validity of the instrument pre-testing was conducted and 25 respondents were selected from UBL (united Bank Limited) and Interest free bank UBL Ameen. In light of pre-testing necessary amendments were made and for ease of respondents and for validation of the study Likert scale was developed. Questionnaire was developed and statements were selected for getting response about dependent and independent variables and also intervening variables were considered, for instance time management, effective communication, and interpersonal relationships, decision making ,financial skills, career management, research skills etc. Descriptive statistics tools (mean, frequency distribution, standard deviation) were used for making a comprehensive summary of data and for brief description of data collected, and inferential statistics were used for exploration of the research question and for the analysis of relationship between variables. 


\section{Results and discussion}

MBA's should have diversified competencies and students should be capable to tackle different aspects. MBA's should have multiple skills in management of business affairs and this study emphasizes on these capabilities which are prominent aspects of MBA degree holders. Different questions were asked for acquiring data about these enhanced skills of MBA degree holders in boundaries of Faisalabad. Different tests were applied for getting the true understanding about relationship between different variables and detail discussion about these tests and their results is stated below.

4.1 Table 1 show the descriptive statistics (Mean, Std. Deviation, St .error) results for responses of MBA's and other business professionals about required skills produced by degree of MBA. These skills provide basis for good managerial jobs .Mean values of statement 1-2, show that respondents are strongly agreed with these statements and MBA's degree can produce good managerial skills \& time management skills .St 3 mean values and Std.deviation value show that this statement is not showing high response of agreement. While statement 4 shows that MBA's are competent like others because its mean value is 2.24 from MBA's response and 2.81 is from other professionals. St. 5-7 shows high mean values and varied St. Deviation and error. So respondents are agreed with these statements, it means MBA degree can enhance capability of stress management, good communication and also good writing skills. St. 8 has mean values of less than 3 it shows that respondents are not strongly agreed with this statement but the response is in middle of the scale. St. 9 shows that business graduates including MBA's have strong oral communication skill. St .10 have contradictory response from MBA'S and non MBA'S because mean value of MBA'S (4.08) shows that respondents are strongly agreed while mean value of other professionals (2.92) shows that response is not as much in the favor of the statement. Majority of respondents are agreed with St. 11 and 12 while with St.13 other professionals are not strongly agreed but MBA's showed positive response. St.14 has not as much strong response of agreement while its mean value and Std. Deviation show that respondents do not strongly agree with the statement which shows that MBA degree produce skill of stress management in holders of it. St 15 has response of agreement from respondents which shows that MBA degree produce financial insight in its holders. St 16 has contradictory response between MBA's and non MBA's. MBA's showed the response of agreement while others showed non agreement response with the statement.

4.2 MBA's are diversified skill holders this is shown by Table 2; this table describes Chi-square, p-values, gamma testing and degree of freedom of each skill with association of MBA. The Chi-Square of 29.13 shows highly significant association $(\mathrm{P}=.00)$ between MBA degree and Time management skill .It shows that degree of MBA can produce better time management skills. Likewise Chi-square of St 2, 4, 5,6,7,8,9,10,11,13 ,15,16 show highly significant association with MBA degree as result theses statements show MBA degree can enhance self confidence, communication skill, effective writing ,oral presentation, research skills ,career advancement, conflict management, stress management, and also decision making skills. While Chi-square of St. 3 and 14 show the value of no significance and this result support previous statements results and explores the facts that MBA degree has great influence on stress management and MBA's are competent from other business graduates.

The findings match with the Dimitrios \& Kristina (2005) who concluded that there is highly significant relationship between degree of MBA and skills enhancement of personals values shows significance relationship among MBA's and these skills mentioned in these statements. St 3 and St 14 showed non significant values because these negative statements were used for checking the reliability of data but results proved that data is reliable.

4.3 Table 3 represents the validation construct and high value of alpha shows that all skills mentioned in above 16 statements are having great link with degree of MBA. MBA's are sharp and competent than others and MBA's are competent enough. Value of Alpha supports results of above analysis done by literature review and statistical applications.

4.4 A t test was applied for checking the significance of these statements with degree of MBA and results shown that all statements are highly significant except St no 3 and ST no 14 .these two statements showed low level of significance so research question is proved through this analysis because these two statements were negative in nature. These results show that MBA are more skillful than other business graduates .MBA's are strong enough in all characteristics mentioned in above statements.

4.5 Table 5 shows the responses about the contribution of MBA degree in employment and career advancement .This table shows the data about MBA degree contribution in employment and career advancement, $45 \%$ people responded that MBA degree helps in fast employment while $35 \%$ responded about its moderate effects, while on the other hand 35\% people responded degree of MBA helps in fast career advancement while $25 \%$ responses were that MBA degree proves better at moderate level for getting promotion. Overall percentages show that degree of MBA is helpful in getting jobs and career advancement.

\section{Conclusion}

The main purpose of this paper was to study the effects of MBA degree on skills development of professionals in Pakistan .It is concluded that MBA's have diversified skills and they get better chances of being promoted and 
being employed. Chi-square analyses show that MBA degrees develop multi skill personalities. All statements tests of significances show that most of the statements are true and MBA's can have career development through this degree. Conclusion drawn from this research is that in Pakistan like other countries MBA's are proving their selves as better managers for business organizations because these personals are strong enough than other professionals.

\section{References}

Ahmed, N. (1997). Demographic and financial characteristics of small business owners. Journal of the American Society of CLU \& ChFC, 51(3), pp. 74-8, doi:10.1108/14626000810850883, http://dx.doi.org/10.1108/14626000810850883

Caceres, A. P. (2008). Mapping the structure of MBA (AMBA-accredited) programs in the UK and France. International Journal of Educational Management, 22 (2), pp.184-209. doi:10.1108/09513540810853576, http://dx.doi.org/10.1108/09513540810853576

Cappelli, P. (1992). Examining managerial displacement. Academy of Management Journal, 35(3), pp.203-17. [Online] Available: http://www.jstor.org

Dimitrios, M. M., \& Kristina, A. E. (2006). Perceived effects of an MBA degree on employability and career advancement: The case of Greece. Career Development International, 11 (4), pp.352 - 361. doi:10.1108/13620430610672559, http://dx.doi.org/10.1108/13620430610672559

Hankinson, A. (2000). The key factors in the profiles of small firm owner-managers that influence business performance: the South Coast Small Firms Survey, 1997-2000.

Hay, A., \& Hodgkinson, M. (2006). Exploring MBA career success. Career Development International, 11(2), pp. 108-124. doi:10.1108/13620430610651877, http://dx.doi.org/10.1108/13620430610651877

Hill, L. A. (2003). Becoming a Manager: How New Managers Master the Challenges of Leadership. Harvard Business School Press. [Online] Available: http://books.google.com.pk

Hill, L. A. (2007). Becoming the Boss. Harvard Business Review, 85(1), pp. 48-56. PMID: 17286074 [Pub Med - indexed for MEDLINE]. [Online] Available: http://www.ncbi.nlm.nih.gov

Hurley-Hanson, A. E., Wally, S., Purkiss, S. L. S., \& Sonnenfeld, J. A. (2005). The changing role of education on managerial career attainment. Personnel Review, 34(5), pp. 517-533. doi:10.1108/00483480510612495, http://dx.doi.org/10.1108/00483480510612495

Kelan, E., \& Jones, R.,D. (2009). Reinventing the MBA as a rite of passage for a boundary less era. Career Development International, 14 (6), pp.547-569. doi:10.1108/13620430910997295, http://dx.doi.org/10.1108/13620430910997295

Kirby, D., A. (2004). Points of view Entrepreneurship education: can business schools meet the challenge? Education $b$ Training. 46 (8/9), pp. 510-519. doi:10.1108/00400910410569632, http://dx.doi.org/10.1108/00400910410569632

Kllie, J. (2004). Management education and management development: Widening participation or narrowing agenda? Journal of European Industrial Training, 28 (8/9), pp.676-688. doi:10.1108/03090590410566598, http://dx.doi.org/10.1108/03090590410566598

Littler, C., Wiesner, R., \& Dunford, R. (2003). The dynamics of delayering: changing management structures in three countries. Journal of Management Studies, 40 (2), pp. 225-56. doi:10.1111/1467-6486.00339, http://dx.doi.org/10.1111/1467-6486.00339

Mahmood, k, \& Shafique, F. (2010). Changing research scenario in Pakistan and demand for research qualified LIS professionals. Library Review, 59(4), pp. 291-303. doi:10.1108/00242531011038596, http://dx.doi.org/10.1108/00242531011038596

Martin, G., and Stains, H. (1994). Managerial competences in small firms. The Journal of Management Development, Vol. 13 No. 7, pp. 23-34. doi:10.1108/02621719410063396, http://dx.doi.org/10.1108/02621719410063396

Mihail, D., M., \& Elefterie, K.A. (2006). Perceived effects of an MBA degree on employability and career advancement: The case of Greece. Journal of Career Development International, 11/ 4, pp. 352 - 361. doi:10.1108/13620430610672559, http://dx.doi.org/10.1108/13620430610672559

Ng, E., S.,W., Burke, R. J., \& Fiksenbaum, L. (2008). Career choice in management: findings from US MBA students. Career Development International, 13 (4), pp. 346-361. doi:10.1108/13620430810880835, http://dx.doi.org/10.1108/13620430810880835

Paton, R., A. (2001). Developing businesses and people: an MBA solution? Journal of Management Development, 20 (3), pp.235-244. [Online] Available: http://www.emeraldinsight.com

Pimpa, N. (2008). Transnational MBA programmes in Thailand. International. Journal of Management in Education, 2 (4), $\quad$ pp. $401 \quad$ - 418.4 [Online] Available: 
http://inderscience.metapress.com/app/home/contribution.asp?referrer=parent\&backto=issue, 3, 6; journal, 7, 13; linkingpublicationresults, 1:120781,1

Ranis, G., Stewart, F., \& Ramirez, A. (2000). Economic growth and human development. World Development, 28 (2), pp. 197-219. Available: http://www.sciencedirect.com/science/article/B6VC6-3YGDD2Y-1/2/ec98f0b97a0dc2faf60b041f4bce9afd

Table 1. Comparison of mean between MBA degree holder and others

\begin{tabular}{|c|c|c|c|c|c|}
\hline Statements about variables & Degree & $\mathbf{N}$ & Mean & $\begin{array}{l}\text { Std. } \\
\text { Deviation }\end{array}$ & Std. Error Mean \\
\hline St 1 & Other & 25 & 3.56 & 1.04 & .21 \\
\hline $\begin{array}{l}\text { MBA is a degree for enhancement of managerial } \\
\text { skills }\end{array}$ & MBA & 75 & 4.56 & .58 & .07 \\
\hline St 2 & Other & 25 & 3.16 & 1.21 & .24 \\
\hline MBA's can manage time in a better way & MBA & 75 & 4.23 & .71 & .08 \\
\hline St 3 & Other & 25 & 2.12 & 1.36 & .27 \\
\hline $\begin{array}{l}\text { MBA's are not competent as other business } \\
\text { graduates. }\end{array}$ & S MBA & 75 & 2.12 & 1.25 & .14 \\
\hline St 4 & Other & 25 & 2.24 & 1.20 & .24 \\
\hline Stress management is prominent quality of MBA's & MBA & 75 & 2.81 & 1.00 & .11 \\
\hline St 5 & Other & 25 & 3.00 & 1.19 & .24 \\
\hline MBA's are good communicators & MBA & 75 & 4.05 & .87 & .10 \\
\hline St 6 & Other & 25 & 3.12 & 1.45 & .29 \\
\hline $\begin{array}{l}\text { MBA degree can develop skill of writing good } \\
\text { presentations }\end{array}$ & $\mathrm{d} \mathbf{M B A}$ & 75 & 4.12 & .80 & .09 \\
\hline St 7 & Other & 25 & 3.24 & 1.42 & .28 \\
\hline MBA's don't feel hesitation & MBA & 75 & 4.20 & .89 & .10 \\
\hline St 8 & Other & 25 & 2.04 & 1.14 & .23 \\
\hline $\begin{array}{l}\text { My oral presentation is very good due to business } \\
\text { graduation }\end{array}$ & S MBA & 75 & 2.13 & .99 & .11 \\
\hline St 9 & Other & 25 & 3.60 & .65 & .13 \\
\hline MBA's are good researchers & MBA & 75 & 4.12 & .77 & .09 \\
\hline St 10 & Other & 25 & 2.92 & .95 & .19 \\
\hline $\begin{array}{l}\text { MBA's have gotten many promotion chances than } \\
\text { other graduates }\end{array}$ & $\mathrm{MBA}$ & 75 & 4.08 & .83 & .10 \\
\hline St 11 & Other & 25 & 3.40 & 1.12 & .22 \\
\hline MBA's can manage conflicts raised by fellows. & MBA & 75 & 3.92 & 1.00 & .12 \\
\hline St 12 & Other & 25 & 3.56 & .96 & .19 \\
\hline MBA'S are good team players. & MBA & 75 & 3.88 & 1.08 & .12 \\
\hline St 13 & Other & 25 & 2.72 & 1.28 & .26 \\
\hline $\begin{array}{l}\text { MBA's can not become victim of great stress during } \\
\text { hours of heavy work load }\end{array}$ & g МBA & 75 & 3.91 & .89 & .10 \\
\hline St 14 & Other & 25 & 2.48 & 1.08 & .22 \\
\hline $\begin{array}{l}\text { MBA's become victim of great stress during hours of } \\
\text { heavy work load though }\end{array}$ & $\mathbf{M B A}$ & 75 & 2.99 & 1.07 & .12 \\
\hline St 15 & Other & 25 & 3.44 & 1.19 & .24 \\
\hline MBA's can handle any financial matter & MBA & 75 & 3.88 & .96 & .11 \\
\hline St 16 & Other & 25 & 2.28 & 1.10 & .22 \\
\hline $\begin{array}{l}\text { MBA'S are good decision makers than other business } \\
\text { graduates. }\end{array}$ & MBA & 75 & 3.27 & 1.13 & .13 \\
\hline
\end{tabular}

Scale: $1=$ strongly disagree, $2=$ Disagree, $3=$ neither agree nor disagree,

$4=$ Agree, $5=$ strongly agree

* St=statement 
Table 2. Distribution of the respondents according to their opinion about diversified skills

\begin{tabular}{|c|c|c|c|c|}
\hline Statements about variables & Chi-square & D.F. & P-value & Gamma \\
\hline $\begin{array}{l}\text { St } 1 \\
\text { MBA is a degree for enhancement of managerial skills }\end{array}$ & 29.13 & 3 & $.00^{* *}$ & .874 \\
\hline $\begin{array}{l}\text { St } 2 \\
\text { MBA's can manage time in a better way }\end{array}$ & 24.83 & 4 & $.00 * *$ & .724 \\
\hline $\begin{array}{l}\text { St } 3 \\
\text { MBA's are not competent as other business graduates. }\end{array}$ & 4.75 & 4 & $.313^{\mathrm{NS}}$ & .032 \\
\hline $\begin{array}{l}\text { St } 4 \\
\text { Stress management is prominent quality of MBA's }\end{array}$ & 8.8 & 4 & $.05^{*}$ & .363 \\
\hline $\begin{array}{l}\text { St } 5 \\
\text { MBA's are good communicators }\end{array}$ & 22.41 & 4 & $.00^{* *}$ & .658 \\
\hline $\begin{array}{l}\text { St } 6 \\
\text { MBA degree can develop skill of writing good } \\
\text { presentations }\end{array}$ & 22.79 & 4 & $.00 * *$ & .526 \\
\hline $\begin{array}{l}\text { St } 7 \\
\text { MBA's don't feel hesitation }\end{array}$ & 18.34 & 4 & $.00^{* *}$ & .510 \\
\hline $\begin{array}{l}\text { St } 8 \\
\text { My oral presentation is very good due to business } \\
\text { graduation }\end{array}$ & 17.45 & 4 & $.00^{* *}$ & .086 \\
\hline $\begin{array}{l}\text { St } 9 \\
\text { MBA's are good researchers }\end{array}$ & 26.36 & 3 & $.00^{* *}$ & .595 \\
\hline $\begin{array}{l}\text { St 10 } \\
\text { MBA's have gotten many promotion chances than } \\
\text { other graduates }\end{array}$ & 25.93 & 3 & $.00^{* *}$ & .779 \\
\hline $\begin{array}{l}\text { St } 11 \\
\text { MBA's can manage conflicts raised by fellows. }\end{array}$ & 16.46 & 4 & $.00^{* *}$ & .343 \\
\hline $\begin{array}{l}\text { St } 12 \\
\text { MBA'S are good team players }\end{array}$ & 11.44 & 4 & $.02 *$ & 271 \\
\hline $\begin{array}{l}\text { St } 13 \\
\text { MBA's can not become victim of great stress during } \\
\text { hours of heavy work load }\end{array}$ & 38.60 & 4 & $.00 * *$ & .634 \\
\hline $\begin{array}{l}\text { St } 14 \\
\text { MBA's become victim of great stress during hours of } \\
\text { heavy work load though }\end{array}$ & 5.94 & 4 & $.20^{\mathrm{NS}}$ & .351 \\
\hline $\begin{array}{l}\text { St } 15 \\
\text { MBA's can handle any financial matter }\end{array}$ & 14.63 & 4 & $.00 * *$ & .295 \\
\hline $\begin{array}{l}\text { St } 16 \\
\text { MBA'S are good decision makers than other business } \\
\text { graduates }\end{array}$ & 18.37 & 4 & $.00^{* *}$ & .559 \\
\hline
\end{tabular}

Table 3. Variable construct

No. of items $=16$

\begin{tabular}{|l|r|r|r|r|r|}
\hline Dependent variable & \multicolumn{1}{|c|}{ Alpha } & Minimum & Maximum & \multicolumn{1}{c|}{ Mean } & \multicolumn{1}{c|}{ Std. Deviation } \\
\hline $\begin{array}{l}\text { Skills development and } \\
\text { career advancement }\end{array}$ & .797 & 53.00 & 46.00 & 69.4200 & 8.93318 \\
\hline
\end{tabular}


Table 4.

\begin{tabular}{|c|c|c|}
\hline Statements about variables & $t$ & Sig. (2-tailed) \\
\hline St 1 & 21770 & \\
\hline MBA is a degree for enhancement of managerial skills & 21.170 & .000 \\
\hline St 2 & & \\
\hline MBA's can manage time in a better way & 23.290 & .000 \\
\hline St 3 & 11708 & 055 \\
\hline MBA's are not competent as other business graduates.. & 11.198 & -055 \\
\hline St 4 & 30.426 & .000 \\
\hline Stress management is prominent quality of MBA's & & \\
\hline St 5 & 26741 & 000 \\
\hline MBA's are good communicators & & \\
\hline St 6 & 35561 & $0 \cap 0$ \\
\hline MBA degree can develop skill of writing good presentations & 50.501 & .000 \\
\hline St 7 & 26865 & 000 \\
\hline MBA's don't feel hesitation & 20.005 & \\
\hline St 8 & 42209 & 000 \\
\hline My oral presentation is very good due to business graduation & & \\
\hline St 9 & 29.867 & .000 \\
\hline MBA's are good researchers & & \\
\hline St 10 & 26.458 & .000 \\
\hline MBA's have gotten many promotion chances than other graduates & 20.450 & \\
\hline St 11 & 24982 & 000 \\
\hline MBA's can manage conflicts raised by fellows. & & \\
\hline St 12 & 30604 & $0 \cap 0$ \\
\hline MBA'S are good team players & 30.094 & .000 \\
\hline St 13 & & \\
\hline $\begin{array}{l}\text { MBA's can not become victim of great stress during hours of heavy } \\
\text { work load }\end{array}$ & 25.155 & .000 \\
\hline St 14 & & \\
\hline $\begin{array}{l}\text { MBA's become victim of great stress during hours of heavy work load } \\
\text { though }\end{array}$ & 9.984 & .075 \\
\hline St 15 & 28306 & $0 \cap 0$ \\
\hline MBA's can handle any financial matter & 28.500 & .000 \\
\hline St 16 & 31735 & 000 \\
\hline MBA'S are good decision makers than other business graduates & & \\
\hline
\end{tabular}

Table 5.

\begin{tabular}{|lllc|}
\hline MBA degree's contribution in Employment & MBA degree's contribution in career advancement \\
\hline None & 0.00 & None & 9.00 \\
Slow & 12.0 & Slow & 18.0 \\
Moderate & 35.0 & Moderate & 25.0 \\
Fast & 45.0 & Fast & 35.0 \\
Very fast & 8.00 & Very fast & 13.0 \\
Mean $=2.49$, SD. $=.810$ & & Mean $=2.25 \quad$ SD $=1.16$ & \\
\hline
\end{tabular}


Appendix

Survey form for research study about impact of degree of MBA in skills enhancement and career advancement

Name

Designation-

Qualification

Age-

Bank-

Contact No-

\begin{tabular}{|c|c|c|c|}
\hline $\begin{array}{l}\text { Strongly } \\
\text { Disagree }\end{array}$ & Disagree & Neutral & Agree \\
\hline
\end{tabular}

St No $1 \quad$ MBA is a degree for enhancement of managerial skills

$Q$ no 1

MBA is degree that provide great business o its MBA degree holders

Q no 2

MBA's can performs various tasks according to requirements of business.

Q no 3

MBA's are commonly diversified skill holders

St No 2 MBA's Can Manage Time In A Better Way

$Q$ no4

time management can be learnt through degree of MBA

$Q$ no 5

MBA s can manage time according to duties in a better way than others.

Q no 6

Time management can rarely find in MBA's

St No 3

MBA's are not competent as other business graduates

Q no 7

MBAs take much time to tackle business affairs than other business graduates

St No 4

$Q$ no 8

MBA can work better in stressful environment

Q no 9

MBAs can be defeated in handling risky projects

$Q$ no 10

MBAs perform efficiently in any type of risky environment

ST No $5 \quad$ MBA's are good communicators

$Q$ no 11

MBAs have good command on oral communication

$Q$ no 12

MBAs can not explore their tacit knowledge properly

$Q$ no 13

MBAs can present any situation in better way of communication

\begin{tabular}{|l|l|l|l|}
\hline & & - & \\
\hline & & - & \\
\hline & & - & \\
\hline
\end{tabular}

St No 6

MBA degree can develop skill of writing good presentations

$Q$ no14

Often MBAs perform assignments of written communication in a

better way than others

St No 7 MBA's don't feel hesitation

Q no 15

MBAs are often much confident than others

St No $8 \quad$ My oral presentation is very good due to business graduation 


\begin{tabular}{|c|c|c|}
\hline $\begin{array}{l}\text { Q no } 16 \\
\text { I can talk and present any topic in an efficient manner }\end{array}$ & & - \\
\hline St No $9 \quad$ MBA's are good researche & & \\
\hline $\begin{array}{l}\text { Q no } 17 \\
\text { MBAs try to find the root causes of any problem and then try to } \\
\text { solve it }\end{array}$ & & - \\
\hline $\begin{array}{l}\text { Q no } 18 \\
\text { Often I feel burden for doing research about any problem }\end{array}$ & & - \\
\hline $\begin{array}{l}\text { Q no } 19 \\
\text { I like to find solutions of the problems of my department }\end{array}$ & & - \\
\hline MBA's have gotten many promotion cha & es than oth & \\
\hline $\begin{array}{l}Q \text { no } 20 \\
\text { According my analysis MBAs have more opportunities in market }\end{array}$ & & - \\
\hline $\begin{array}{l}\text { Q no } 21 \\
\text { MBAs can develop their career easily as compare to others }\end{array}$ & & - \\
\hline $\begin{array}{l}Q \text { no } 22 \\
\text { At the same rank an MBA can be promoted quickly than any other } \\
\text { professional }\end{array}$ & & - \\
\hline MBA's can manage conflicts raised by 1 & ows. & \\
\hline $\begin{array}{l}\text { Q no23 } \\
\text { I can understand reasons of conflicts among fellows }\end{array}$ & & - \\
\hline $\begin{array}{l}\text { Q no24 } \\
\text { Often my colleges ask me to tell us the solution of any dispute } \\
\text { raised. }\end{array}$ & & - \\
\hline $\begin{array}{l}\text { Q no25 } \\
\text { I don't think so I can handle or solve problems and conflicts of } \\
\text { others }\end{array}$ & & - \\
\hline MBA'S are good team play & & \\
\hline $\begin{array}{l}\text { Q no26 } \\
\text { MBAs are sharp enough in development of teams }\end{array}$ & & - \\
\hline St No 13 MBA's can not become victim of great stress durin & hours of he & \\
\hline $\begin{array}{l}\text { Q no27 } \\
\text { I often do work in great pressure but I manage it effectively }\end{array}$ & & - \\
\hline St No 14 MBA's become victim of great stress during hours & heavy wor & \\
\hline $\begin{array}{l}\text { Q no28 } \\
\text { I can not handle problems under great stress }\end{array}$ & & - \\
\hline St No $15 \quad$ MBA's can handle any financial ma & & \\
\hline $\begin{array}{l}\text { Q no29 } \\
\text { MBA are skillful in tackling financial matters }\end{array}$ & & - \\
\hline St No 16 MBA'S are good decision makers than other busine & graduates & \\
\hline $\begin{array}{l}\text { Q no30 } \\
\text { MBAs can perform as good decision makers }\end{array}$ & & - \\
\hline
\end{tabular}

